Piotr Krakowiak*

Toruń

\title{
Edukacyjne funkcje wolontariatu i ich percepcja w nauczaniu Kościoła w XXI wieku
}

Wzajemna pomoc międzyludzka jest elementem każdej cywilizacji i społeczeństwa, dlatego można powiedzieć, że historia wolontariatu jest równie antyczna, jak istnienie rodzaju ludzkiego ${ }^{1}$. Chcąc zbadać zjawisko wolontariatu, należy najpierw przyjrzeć się inspiracjom do podejmowania tego rodzaju działań i rozumieniu terminu „,wolontariusz”. Poznanie różnych źródeł motywacji podejmowania ochotniczych działań, analiza motywacji właściwych wolontariatowi oraz współczesnego jego rozumienia pozwoli na zdefiniowanie tego pojęcia. Ukazanie zainteresowań nauk społecznych i nauk o wychowaniu tematyką wolontariatu pokaże jego funkcje edukacyj$n^{2}$. Prześledzenie wypowiedzi papieży XXI wieku: Jana Pawła II, Benedykta XVI oraz Franciszka, nawiązujących do organizacji i wartości wolontariatu, pozwoli ukazać rolę, jaką ochotnicze zaangażowanie w pomoc bliźniemu odgrywać może w formacji ludzkiej i chrześcijańskiej. Słowa oficjalnego nauczania Kościoła katolickiego odnośnie do wolontariatu były pomocne w rozwoju ochotniczego zaangażowania w opiekę paliatywno-hospicyjną i znalazły się w podręczniku dla jej koordynatorów3 ${ }^{3}$. Lektura i analiza tek-

* Ks. dr hab. Piotr Krakowiak jest adiunktem w Katedrze Pracy Socjalnej na Wydziale Nauk Pedagogicznych Uniwersytetu Mikołaja Kopernika w Toruniu.

${ }^{1}$ H. Klimaszewska, C. Opalach, Wolontariat hospicyjny - analiza psychologiczna na przykładzie Lubelskiego Hospicjum dla Dzieci, w: J. Makselon (red.), Człowiek wobec śmierci. Aspekty psychologoczno-pastoralne, Kraków 2005, s. 279-280.

${ }^{2}$ Por. P. Krakowiak, Wolontariat w opiece u kresu życia, Torun 2012.

${ }^{3}$ D. Giers, P. Krakowiak, Kościół katolicki wobec wolontariatu i posługi wolontariuszy, w: P. Krakowiak, A. Modlińska, J. Binnebesel (red.), Podręcznik koordynatora wolontariatu hospicyjnego, Gdańsk 2008, s. 257-273. 
stów odnoszących się do wolontariatu może stać się inspiracją zarówno dla duchownych, jak i świeckich, by wykorzystywać instytucję wolontariatu do pomocy ludziom w potrzebie. Powinny być również zachętą do wychowywania poprzez służbę innym, uczenia w praktyce, czym jest solidarność międzyludzka i chrześcijańskie miłosierdzie. Poniższe rozważania mogą być pomocne zarówno dla teoretyków wychowania chrześcijańskiego, jak również dla praktyków, którzy w szkołach, parafiach czy w strukturach Caritas $\mathrm{i}$ innych organizacji charytatywnych są zaangażowani w wolontariat lub nim koordynuja.

\section{Ewolucja pojęcia wolontariatu w Europie i na świecie}

Wzajemna pomoc w wymiarze lokalnej wspólnoty była i jest niezbędna do przetrwania wszędzie tam, gdzie pomoc $\mathrm{w}$ zbiorach, budowie domu, opieka nad starcami i niepełnosprawnymi są ciagle naturalnymi elementami funkcjonowania lokalnych wspólnot. W świecie wysoce cywilizowanym, do którego zaliczamy Europe, procesy industrializacji i urbanizacji doprowadziły do anonimowości w społecznościach zurbanizowanych miast, podważając wartość solidarności międzyludzkiej i wzajemnej pomocy ${ }^{4}$. Wolontariat przez wieki rozumiano jako praktykowanie bez wynagrodzenia dla nauczenia się zawodu lub ochotniczą służbę wojskową wobec zagrożenia ojczyzny $^{5}$. W ostatnim stuleciu termin ten został zdefiniowany w szerszym ujęciu, jako wkład jednostek w bezinteresowna, nieodpłatną i niezawodową działalność dla dobra lokalnej wspólnoty lub całego społeczeństwa ${ }^{6}$. Nowożytne przemiany społeczno-gospodarcze w Europie nie sprzyjały społecznemu wspieraniu ludzi w potrzebie, gdyż homo oeconomicus musiał troszczyć się coraz bardziej o siebie i swoją rodzinę . $^{7}$

Najnowszą historię Europy charakteryzowały dynamicznie zmieniające się struktury społeczeństw, a także kulturalnych i religijnych uwarunkowań życia poszczególnych osób i całych społeczności. Masowym zjawiskiem były emigracje na nowe kontynenty i ruchy ludnościowe. Społeczne zaangażowanie i wsparcie wiązało się z falami emigracji z Europy do obu Ameryk. Aby przetrwać, emigranci musieli ze sobą współpracować, dlatego powsta-

${ }^{4}$ Por. W. Reinhard, Życie po europejsku. Od czasów najdawniejszych do współczesności, Warszawa 2009.

${ }^{5}$ Por. P. Krakowiak, Wolontariat, s. 74.

${ }^{6}$ Por. M. Górecki, Wolontariat, w: D. Lalak, T. Pilch (red.), Elementarne pojęcia pedagogiki społecznej i pracy socjalnej, Warszawa 1999, s. 336.

${ }^{7}$ K. Kabasiński, P. Krakowiak, Filozoficzno-etyczne podstawy altruizmu, w: P. Krakowiak, A. Modlińska, J. Binnebesel (red.), dz. cyt., s. 200-210. 
jące społeczności obywatelskie były jednym z prototypów współczesnego społeczeństwa obywatelskiego, z którym wiazże się fenomen wolontariatu'. Początek oficjalnych historii instytucji zrzeszających wolontariat w Stanach Zjednoczonych datuje się na 1896 rok, gdy została utworzona organizacja Volunteers of America ${ }^{9}$. Wiele organizacji międzynarodowych promujących wolontariat powstało z inicjatywy społeczeństwa obywatelskiego Stanów Zjednoczonych w XX wieku. UNESCO powołało do życia instytucję mającą ułatwić współpracę i koordynację organizacji wolontariackich CCIVS, zrzeszająca obecnie ponad 140 organizacji ${ }^{10}$. Najbardziej rozwinięte struktury wolontariatu istnieją w krajach mających duże tradycje obywatelskiej aktywności i zaangażowania społecznego, wywodzące się z doświadczeń emigrantów, jak Stany Zjednoczone czy Kanada ${ }^{11}$.

Współczesne znaczenie w Europie słowa „wolontariusz” uformował w 1920 roku szwajcarski pacyfista i chrześcijanin, Pierre Ceresole, uważany za twórcę dzieła Service Civil Volontaire ${ }^{12}$. Utworzony przez niego zespół ochotników stał się kamieniem milowym w rozwoju nowoczesnego wolontariatu międzynarodowego, działającego wbrew uprzedzeniom i nacjonalizmom ${ }^{13}$. Unia Europejska od lat promuje wolontariat, a poszerzanie jej o nowe państwa umożliwiło zrzeszanie się instytucji państwowych w sieci współpracy, prowadzenie wspólnych działań oraz rozszerzenie zasięgu działania. Urzędy Unii Europejskiej opracowały dyrektywy ułatwiające działanie tego typu organizacji na terenie wspólnoty. Zostały wdrożone programy, pomagające w finansowaniu tych przedsięwzięć, na przykład w ramach Europejskiej Sieci Wolontariatu (EVS) ${ }^{14}$.

\section{Rozwój wolontariatu w Polsce}

Działania charytatywne i wolontaryjne podejmowane były w ciagu całej historii państwa polskiego przez liczne wspólnoty wyznaniowe, szczególnie

${ }^{8}$ Por. S. J. Ellis, K. H. Campbell (red.), By the People: A History of Americans as Volunteers, Washington 2005.

${ }_{9}$ Por. www.voa.org/About-Us/Our-History/ (grudzień 2013).

${ }^{10}$ Por. http://www.unesco.org/ccivs/ (grudzień 2013).

${ }^{11}$ I. Kość, E. Zator, Wolontariat w kraju pachnacym żywica, w: B. Kromolicka (red.), Wolontariat w obszarze humanistycznych wyzwań opiekuńczych, Torun 2005.

12 Por. O. Bertrand (red.), Breaking Down Barriers. 1945-1975, 30 years of voluntary service for peace with Service Civil International, Geneva 2009.

${ }_{13}$ Por. A. Gillette, One million volunteers. The Story of Volunteer Youth Service, London 1968

${ }^{14}$ European Voluntary Service, w: http://www.wolontariat.edu.pl/historia-wolontariatuw-europie (styczeń 2014). 
przez zakony męskie i żeńskie ${ }^{15}$. Działania społeczne w kraju pod zaborami realizowali romantycy i pozytywiści, propagatorzy powszechnej edukacji, pomagający przez pracę u podstaw w środowiskach lokalnych. Czas szczególnego zrywu społecznikowskiego łączył się z odzyskaniem niepodległości i nowymi nadziejami społecznymi, które wiązały się ze społecznym zaangażowaniem i wolontariatem ${ }^{16}$. Przykładem takich działań w naukach o wychowaniu były przedsięwzięcia Heleny Radlińskiej związane ze społecznym zaangażowaniem pierwszych studentów i stworzeniem Studium Pracy Społeczno-Oświatowej w Wolnej Wszechnicy Polskiej w Warszawie. Obok prac dydaktyczno-oświatowych, jednym z obszarów jej zainteresowań była oświata zdrowotna, w której ochotnicy mieli wspierać pielęgniarki ${ }^{17}$. Ważnymi ośrodkami ochotniczej pracy były instytucje religijne, związane głównie z Kościołem katolickim, ale także z innymi wyznaniami chrześcijańskimi, wspólnotami żydowskimi na terenach przedwojennej Polski ${ }^{18}$.

Po roku 1945 w Polskiej Rzeczpospolitej Ludowej założenie jakiejkolwiek niezależnej od struktur państwowych organizacji było niemożliwe z powodów ideologicznych. Państwo przejmowało i kontrolowało istniejące organizacje społeczne. Pracę ochotniczą traktowano jako obszar podporządkowany władzy, a nakazywane prace społeczno-użyteczne były zajęciem obdarzanym niechęcią w szkołach i zakładach pracy. Praca społeczna stała się narzędziem propagandowym, negatywne skutki takiego odbioru działań charytatywnych miały między innymi nacjonalizacja katolickiej Caritas, a także odbieranie zakonom szpitali i domów pomocy dla potrzebujących i starszych ${ }^{19}$.

Od roku 1980 Solidarność przyniosła zmiany w społecznym zaangażowaniu do wolontariatu, wśród których szczególnym przykładem może być powstanie i rozwój ruchu hospicyjnego. W 1981 roku zarejestrowano w Krakowie Towarzystwo Przyjaciół Chorych Hospicjum, w którym wolontariusze nieśli pomoc nieuleczalnie chorym. Od 1983 roku w Gdańsku grupa wolontariuszy udawała się do chorych z domową opieką hospicyjną. W 1984 roku uchwalono Ustawe o fundacjach, szukając alternatywy dla nieformalnych struktur wolontariatu w Polsce, reprezentowanych w tym czasie przez kościelne grupy oazowe i wywodzące się z organizacji kościelnych, a w roku

${ }^{15}$ R. Jusiak, Inspiracja chrześcijańska w pedagogice opiekuńczej, w: A. Olubiński (red.), Tożsamość oraz dylematy pedagogiki opiekuńczej, Toruń 2001, s. 64.

${ }^{16}$ R. Wroczyński, Wstęp - Helena Radlińska, w: H. Radlińska, Pedagogika spoteczna, Wrocław-Warszawa-Kraków 1961, s. X-XII.

${ }^{17}$ Por. H. Radlińska, Stużba społeczna pielęgniarki, Warszawa 1935.

${ }^{18}$ Por. W. Przygoda, Postuga charytatywna Kościoła w Polsce, Lublin 2004.

19 Por. P. Krakowiak, Wolontariat, s. 80. 
1989 uchwalono Ustawę o stowarzyszeniach ${ }^{20}$. Jedną z pierwszych organizacji wolontariackich w Polsce było zarejestrowane w 1992 roku Ogólnopolskie Forum Ruchu Hospicyjnego (OFRH $)^{21}$. Wolontariat, budowany na wzór struktur europejskich, stawiał w Polsce pierwsze kroki, gdy powstało pierwsze Centrum Wolontariatu, inspirując do utworzenia sieci podobnych placówek. Swoistym fenomenem, który przyczynił się do propagowania wolontariatu w Polsce po demokratycznych przemianach, stał się Jerzy Owsiak, zachęcający młodzież do wolontariatu, a całe społeczeństwo do wspierania Wielkiej Orkiestry Świątecznej Pomocy. Fundacja od 1992 roku prowadzi działania na rzecz ciężko chorych dzieci i seniorów, a swoje działania w dużym stopniu opiera na wolontariacie ${ }^{22}$. Mniej widoczne w mediach publicznych, ale systematycznie działające $\mathrm{w} 44$ diecezjach w Polsce były rozpoczęte od 1990 roku działania Caritas, korzystające z pomocy wolontariuszy w parafialnych zespołach Caritas i Szkolnych Kołach Caritas w całym kraju. Szczegółowy opis działań koordynowanych przez Caritas Polska z opisem edukacyjno-charytatywnych inicjatyw z udziałem wolontariatu został opublikowany z okazji 20-lecia działania tej organizacji ${ }^{23}$.

Pierwsze zapisy o wolontariacie w aktach prawnych pojawiły się w Polsce dopiero w 2000 roku, przed ogłoszeniem przez ONZ roku 2001 Światowym Rokiem Wolontariatu, co wymusiło na rządzących podjęcie działań. Od 29 czerwca 2003 roku obowiązuje w Polsce Ustawa o dziatalności pożytku publicznego $i$ o wolontariacie ${ }^{24}$. Ten istotny dla ochotniczego zaangażowania dokument określił wolontariat jako ważny element budowania społeczeństwa obywatelskiego ${ }^{25}$. Sektor organizacji pozarządowych w Polsce jest ciagle kształtującą się sferą życia społecznego. Badania wolontariatu w Unii Europejskiej z 2011 roku ukazują, że Polska jest ciagle poniżej średniej EU w społecznym zaangażowaniu i wolontariacie pośród krajów członkowskich $^{26}$. Zaangażowanie obywateli jest wyzwaniem dla społeczeństwa polskiego, stąd ważne jest poznanie motywacji do ochotniczej pomocy, co

${ }^{20}$ P. Komosa, Status i formy organizacyjne organizacji pozarzadowych $w$ Polsce, „Roczniak” (1995), s. 11.

${ }^{21}$ M. Kalinowski, Wspólnoty nadziei, Lublin 2007, s. 68.

${ }^{22}$ Por. http://www.wolontariat.edu.pl/wosp-wielka-orkiestra-swiatecznej-pomocy/ (styczeń 2013).

${ }^{23}$ Caristas Polska, W stużbie ludziom - Raport Caritas w Polsce, Warszawa 2010.

${ }^{24}$ Dz. U. Nr 96, poz. 873 ze zm.

${ }_{25}$ Por. http://ec.europa.eu/youreurope/citizens/education/volunteering/index_pl (styczń 2014).

${ }^{26}$ Por. Eurobarometr: Młodzi Polacy nie angażuja się $w$ wolontariat; za: JAPA, PAP, w: http://spoleczenstwo.newsweek.pl/eurobarometr--mlodzi-polacy-nie-angazuja-sie-w-wolontariat,76828,1,1.html (grudzień 2013). 
ukazują badania w obszarze nauk o wychowaniu, w tym szczególnie psychologii i pedagogiki.

\section{Zainteresowanie wolontariatem w naukach o wychowaniu}

Siła wolontariatu tkwi w potencjale osobowym i nastawieniu motywacyjnym poszczególnych ludzi, którzy niosą pomoc innym. W działalność wolontariacką jest wpisana postawa altruistyczna. Wspólną cechą wszystkich form altruizmu i ich celem jest zwiększenie dobrobytu innych, a ofiara $\mathrm{z}$ siebie to wyraz miłości, aż do ofiary $\mathrm{z}$ własnego życia ${ }^{27}$. Osoby o prospołecznym nastawieniu, zaangażowane $\mathrm{w}$ wolontariat częściej przejawiają gotowość do okazywania innym dobroci, sympatii, serdeczności, zwłaszcza względem ludzi słabszych, będących w trudnej sytuacji życiowej czy potrzebujących pomocy ${ }^{28}$. Wolontariat zaspokaja potrzebę bycia użytecznym dla drugiego człowieka, otwierając ochotnika na kontakty z innymi ludźmi. „Wolontariusz żyje i działa pod wpływem sił wewnętrznych - duchowych, co sprawia, że naturalnie i z przekonaniem podtrzymuje kontakty międzyosobowe. To osoba mocna, lecz nie agresywna, harmonijna, kochająca - ponieważ kieruje się miłością, bo chce być blisko innych, pragnie ich dobra, szanuje ich wolność, okazuje im serdeczną przyjaźń i unika stosowania przymusu lub okazywania władzy"29. Wolontariusze oprócz swoich wewnętrznych motywacji powinni wykazywać się kompetencjami, posiadanymi z racji doświadczenia zawodowego lub kwalifikacjami nabytymi podczas szkoleń. Istnieją programy edukacyjne, przygotowujące ludzi dobrej woli do profesjonalnej pracy $\mathrm{w}$ wolontariacie, będącym elementem działania profesjonalnych zespołów opiekuńczych. Wolontariat umożliwia wychowanie przez spotkanie z drugim człowiekiem: cierpiącym, potrzebującym, odrzuconym. „Istnieją prawdy, których można nauczyć się z książki, do których można dojść przez intelektualne spekulacje. Lecz są także takie prawdy, na które nie ma teoretycznej odpowiedzi. Można je poznać jedynie przez osobiste świadectwo i własne życiowe doświadczenie" ${ }^{30}$.

27 Por. V. Jeffries et al., Altruism and Social Solidarity: Envisioning a Field of Specialization, The American Sociologist, Fall 2006, s. 67-68.

28 J. Kahlan, Wolontariat w procesie resocjalizacji skazanych, w: B. Kałdon, I. Kurlak (red.), Uwarunkowania, profilaktyka i resocjalizacja aspolecznych zachowań dzieci i młodzieży, Warszawa 2010, s. 145.

${ }_{29}$ B. Bugajska, Bariery w działalności organizacji pozarzadowych, w: B. Kromolicka (red.), Wolontariat w obszarze humanistycznych wyzwań opiekuńczych, Toruń 2005, s. 226.

${ }^{30}$ T. Gadacz, Wychowanie jako spotkanie osób, „Znak” 9 (1991), s. 47. 
Nauki o wychowaniu widzą $\mathrm{w}$ wolontariacie nie tylko zachowanie prospołeczne, wynikające z motywacji humanistycznych i duchowych, ale także szansę zdobycia doświadczenia zawodowego i perspektywę owocnych praktyk zawodowych. Wolontariat może stanowić rodzaj kształcenia ustawicznego, którego efektem może być lepsza pozycja na rynku pracy. To ,proces przedłużonego i poszerzonego kształcenia prowadzący do wzbogacenia intelektu i osobowości jednostki zgodnie z jej potrzebami”" ${ }^{\prime 1}$. Przez pedagogów szkolnych wolontariat postrzegany jest jako narzędzie edukacji społecznej dzieci i młodzieży, gdyż „stanowi doskonałą okazję do uświadomienia sobie społecznie uniwersalnych wartości. W ten sposób kształtuje się wewnętrzną motywację do pracy" ${ }^{\prime 32}$. Pedagodzy apelują o odpowiednie przygotowanie i koordynację działań ochotników, przypominając, iż praca wolontariusza powinna być zorganizowana i wykonywana w sposób profesjonalny. Wolontaryjne zaangażowanie wskazuje na chęć do działania, związanego z odpowiedzialnością, kreatywnością, umiejętnością samodzielnego myślenia i działania w grupie. W przypadku edukacji osób dorosłych i starszych wolontariat daje szansę odnalezienia miejsca w społeczeństwie, odpowiedniego do nowych możliwości i planów osobistych lub zawodowych $^{33}$. Badacze zagadnienia przypominają iż osoba pomagająca ponosi koszty ochotniczego zaangażowania, ale otrzymuje w zamian nowe kompetencje. Koszty to wysiłek związany z pracą wolontarystyczna, poświęcony czas i emocjonalne zaangażowanie w sytuacjach kryzysowych. Korzyściami są aprobata społeczna, wdzięczność osób otrzymujących wsparcie, satysfakcja $\mathrm{z}$ wykonywanych zadań i zdobycie nowych kompetencji, przydatnych w zdobyciu pracy lub nowych kwalifikacji ${ }^{34}$. Ważne jest w procesie przygotowania wolontariuszy, by uświadomić im również trud podejmowanych działań i realizm pomocy osobom w kryzysie, wskazując, że za ich pomoc mogą ich spotkać brak wdzięczności, niezrozumienie czy negatywne lub agresywne postawy ze strony podopiecznych ${ }^{35}$.

Wśród nauk pedagogicznych zagadnieniami wolontariatu zajmuje się szczególnie pedagogika społeczna. Jej rozwój, wraz z tworzącą się pracą socjalną w Polsce, wywodził się z ochotniczego zaangażowania na rzecz po-

${ }^{31}$ Z. Wiatrowski, Podstawy pedagogiki pracy, Bydgoszcz 2000, s. 366.

${ }^{32}$ P. Skrzypecki. Uczniowski wolontariat jako metoda wychowawcza, w: H. Krzystenko (red.), Rodzina $w$ trudnej sytuacji życiowej $i$ wychowawczej wyzwaniem dla wolontariatu, Katowice 2001, s. 31-33.

${ }^{33}$ Por. Z. Tarkowski, Zarzadzanie i organizacja pomocy społecznej, Lublin 2000.

${ }^{34}$ Por. E. Aronson, T. D. Wilson, R. M. Akert, Psychologia społeczna. Serce i umyst, Poznań 1997.

${ }^{35}$ Por. L. Witkowski, Praca socjalna i profesjonalizm pedagogiczny, Łódź 2010, s. $93-105$ 
trzebujących. Pedagogika społeczna podkreśla wartość pracy wolontariuszy, jako odpowiedzialnej służby społecznej w formie bezpłatnej, dobrowolnej, ochotniczej i świadomej pracy stałej lub okazjonalnej na rzecz innych. Praca wolontariuszy jest trudnym i odpowiedzialnym zadaniem społecznym. Wymaga nie tylko bezinteresownego poświęcenia własnych sił dla dobra drugiego człowieka, ale przede wszystkim determinacji, wrażliwości, wytrzymałości, umiejętności łączenia współczucia ze sprawnością działania, wyrozumiałości, cierpliwości, dyscypliny emocjonalnej - a więc cech, które znamionują dojrzałą osobowość i układają się w postawę roztropnej życzliwości. Niegdyś wolontariusz definiowany był mianem społecznika, filantropa lub altruisty, ale współcześnie jest to osoba, która ochotniczo i bez wynagrodzenia wykonuje świadczenia na zasadach określonych w ustawie ${ }^{36}$.

Obok motywacji i formy ochotniczej pracy, odpowiedzialnego podejścia do wypełnianych zadań, podkreślane jest znaczenie ciagłości pracy wolontariuszy, w której czas jest istotnym wskaźnikiem skuteczności działań wolontariatu. W tym ujęciu jednorazowe, akcyjne działanie nie spełnia cech wolontariatu i może być traktowane najwyżej jako wstęp do niego ${ }^{37}$. Związanie wolontariusza $\mathrm{z}$ organizacją, regularne wykonywanie zobowiązań, często w określonych terminach (dniach, godzinach) oznacza wolontariat stały. Zwykle współpraca ta opiera się na porozumieniu podpisanym przez obie strony. Socjologowie, psychologowie i pedagodzy zajmujący się tematyką wolontariatu zgadzają się co do tego, że wolontariat zaczyna się tam, gdzie człowiek jest gotowy nieodpłatnie, z własnej woli, wskutek wewnętrznego przekonania oferować swoją pomoc osobom jemu nieznanym ${ }^{38}$. To wewnętrzne przekonanie wiąże się $\mathrm{z}$ duchowymi lub humanistycznymi wartościami, motywującymi ochotników do pomocy innym.

\section{Duchowe i humanistyczne źródła motywacji do podejmowania wolontariatu}

Badacze zachowań prospołecznych poszukujący źródeł altruizmu wskazują często na religijny charakter ludzkich zachowań i wpływ religii na podejmowanie działań pomocowych ${ }^{39}$. W historii Europy nie brak przykła-

36 Por. Dz.U. z 2003 r. Nr 96, poz. 873 z późn. zm., art. 2. pkt 3.

${ }^{37}$ Por. B. Kromolicka, Wolontariat, w: T. Pilch (red.), Encyklopedia pedagogiczna XXI wieku, t. VII, Warszawa 2008, s. 223.

${ }_{38}$ T. Kamiński, Wolontariat w placówkach pomocy instytucjonalnej, „Roczniki Naukowe Caritas" 5 (2001), s. 102.

${ }^{39}$ Por. W. Przygoda, Wolontariat chrześcijański w życiu i działaniu Kościoła, „Roczniki Naukowe Caritas" 5 (2001), s. 39-58. 
dów pomocy świadczonej bez wynagrodzenia w imię ideałów chrześcijańskich, zarówno przez osoby duchowne, jak i przez świeckich, zainspirowanych przykładem miłosiernego Samarytanina. W pewnym sensie wszystkie dzieła chrześcijańskiego miłosierdzia można zaliczyć do kategorii protoplastów dzisiejszego wolontariatu. Empiryczne badania religijnych źródeł zachowań prospołecznych dają odpowiedź na hipotezę, że religie ułatwiają altruistyczne zachowania i gotowość do wolontariatu na rzecz innych osób i społeczności ${ }^{40}$. Analizy wykazują związek pomiędzy religijnością i postawą społecznikowską, co potwierdzają także międzykulturowe badania różnych religii ${ }^{41}$. Zachęcając wiernych do prospołecznych zachowań, systemy religijne sprawiaja, iż w tych samych społecznościach osoby religijnie są bardziej zaangażowane społecznie od osób niereligijnych ${ }^{42}$. Religijność wolontariuszy jest angażującą formą przeżywania kontaktu z Bogiem, postrzeganym jako bliski Przyjaciel. Jego Osoba integruje cały świat wartości, jakimi kierują się ochotnicy, a relacja między nimi a Bogiem ma charakter wzajemnej ufności, obecności i miłości. Najważniejszymi źródłami motywacji do wolontariatu są zatem potrzeby duchowo-religijne i humanistyczne, nakazujące bezinteresowną pomoc bliźniemu. Chrześcijańskie miłosierdzie to nie tylko altruizm i pojedyncze gesty, ale to nade wszystko troska o całokształt osoby ludzkiej ${ }^{43}$. Nie wystarczy chrześcijaninowi mówić: „chcę, mogę, potrafię”, lecz potrzeba o wiele głębszego: „rozumiem, chcę, potrafię i wytrwam” ${ }^{4}$. Także w innych religiach istnieją wezwania do bezinteresownej służby, choć uwarunkowania kulturowe i społeczne powoduja różnice zaangażowania w wolontariat, nawet wśród wyznań chrześcijańskich. Zaangażowanie z motywów duchowo-religijnych zostało zbadane i opisane w analizach zaangażowania się w wolontariat w strukturach katolickiej Caritas ${ }^{45}$.

Systemy duchowo-religijne ze swoimi wartościami nadal wpływają na społeczne zachowania wielu osób, ale nie są ich jedynymi źródłami. Wiarygodność instytucji świeckich, organizacji pozarządowych i humanitarnych

40 A. Norenzayan, A. F. Shariff, The Origin and Evolution of Religious Prosociality, "Science" 322 (2008), s. 58-62.

${ }^{41}$ Por. A. Brooks, Who Really Cares? The Surprising Truth About Compassionate Conservatism, New York 2006.

${ }^{42}$ C. D. Batson, P. Schoenrade, W. L. Ventis, Religion and the Individual, New York 1993.

${ }^{43}$ Por. J. Tischner, Świat ludzkiej nadziei, Kraków 2000.

${ }^{44}$ D. Giers, P. Krakowiak, dz. cyt., s. 270-272.

${ }^{45}$ T. Kamiński, Praca socjalna i pracownicy socjalni $w$ kościelnych organizacjach pozarzqdowych, w: M. Rymsza (red.), Pracownicy socjalni i praca socjalna w Polsce. Między stużbq spolecznq a urzędem, Warszawa 2012, s. 299-304. 
zmienia bieg ludzkich zachowań w życiu społecznym ${ }^{46}$. Przykłady społeczeństw postreligijnych w Europie wskazują, że bez religii udaje się zachować duży poziom społecznego zaufania i współpracy z zaangażowaniem $\mathrm{w}$ wolontariat i zachowaniami prospołecznymi ${ }^{47}$. Nie umniejszając znaczenia motywacji religijnych, będących przyczyną zaangażowania $\mathrm{w}$ działania wolontariatu, przy analizie motywacji ochotników należy brać pod uwagę także jego pozareligijne źródła. Obok osób motywowanych religijnie ${ }^{48}$, nie brak ludzi ofiarujących swoją energię dla innych w duchu ludzkiej solidarności. Jean-Henri Dunant, wstrząśnięty cierpieniami rannych i brakiem opieki medycznej, organizował pomoc, a swe doświadczenia opisał w książce, która stała się inspiracją do stworzenia międzynarodowej organizacji wolontariackiej - Czerwonego Krzyża ${ }^{49}$. Potrzebę solidarności społecznej potwierdził rozwój tej organizacji, opartej w dużej mierze na wolontariacie, z rzeszą ponad 97 milionów ochotników współpracujących na całym świecie w licznych projektach i w akcjach pomocy humanitarnej ${ }^{50}$. Obok motywacji religijnej drugą grupę stanowią inspiracje humanistyczne. Spośród myślicieli humanistycznych warto przytoczyć Tadeusza Kotarbińskiego, który widział w wolontariacie poszukiwanie sensu życia. „Kto szuka sensu życia, szuka tego samego właśnie, o to właśnie zatroskany, by jego czyny nie były bezcelowe a ściślej, by jego działalność nie wyczerpywała się w błahych przedsięwzięciach, lecz mogła się legitymizować przydatnością do celu godnego poświęcenia mu głównych najważniejszych wysiłków" ${ }^{51}$. Przy innej okazji mówił także o konieczności społecznego zaangażowania:

Środowiskom, które chcą działać skutecznie, bardziej powinno zależeć na ludziach, którzy potrafią cofnąć się przed wykonaniem rozkazu, niż na takich ludziach, którzy nie mają żadnych nigdy pod żadnym względem sprzeciwów. Dlatego, że ci pierwsi ludzie są cennymi współdziałaczami na daleki dystans, a ci, którzy mają skłonność do absolutnego poddania się instrukcji, mogą być pożyteczni doraźnie, ale na nich nie można stawiać na daleki dystans ${ }^{52}$.

${ }^{46}$ Por. N. S. Henrich, J. Henrich, Why Humans Cooperate: A Cultural and Evolutionary Explanation, Oxford 2007.

47 Por. A. Norenzayan, A. F. Shariff, dz. cyt., s. 58-62.

${ }^{48}$ R. Jusiak, dz. cyt., s. 63-64.

49 Por. Dunant, J. Henry, A Memory of Solferino, Geneva 1986.

${ }_{50}$ Por. D. P. Forsythe, The Humanitarians: The International Committee of the Red Cross, Cambridge 2005.

51 T. Kotarbiński, Medytacje o życiu godziwym, Warszawa 1976, s. 22.

52 Rozmowa A. Małachowskiego z T. Kotarbińskim, „Literatura” 15 (1972), s. 15. 
Na pytanie, dlaczego ludzie angażują się w działalność wolontariacką, padają różne odpowiedzi. Marta Wyszyńska wymienia szereg motywacji wolontariuszy ze względu na wyznawane przez nich wartości oraz potrzeby emocjonalne. Kategorie potrzeb, które mają wpływ na ochotnicze zaangażowanie to: (1) samoocena, (2) poczucie obowiązku, (3) wiara religijna, (4) wpływ innych, (5) korzyści społeczne. Głównym motywem zachowań prospołecznych może być realizacja określonego celu, realizowanego dla własnego dobra. Może nim być uzyskanie korzyści materialnych i pozamaterialnych, podwyższenie pozycji społecznej, poprawa własnego wizerunku, sposób radzenia sobie z własnymi emocjami i nastrojami poprzez redukcje napięcia emocjonalnego $0^{53}$. Typologie motywacji kierujących ludzi do ochotniczej pomocy są ważną z perspektywy nauk o wychowaniu, ale przybliżoną próbą opisu rzeczywistości związanej z ich najgłębszymi źródłami, czy - jak chcą niektórzy $-\mathrm{z}$ powołaniem do bycia wolontariuszem ${ }^{54}$. Altruizm, powołanie, bezinteresowność podejmowanych działań i duchowo-religijne oraz humanistyczne źródła motywacji do podejmowania wolontariatu wskazuja, iż tym zagadnieniem powinien zajmować się w swoim nauczaniu Kościół katolicki, co zostanie przeanalizowanie na podstawie fragmentów nauczania trzech ostatnich Biskupów Rzymu i ich wypowiedzi.

\section{Jan Paweł II promotorem chrześcijańskiego wolontariatu}

W dokumentach Soboru Watykańskiego II ani razu nie padło słowo wolontariat, ale wielokrotnie wspominają one o konieczności zaangażowania chrześcijan w pomoc, dzieła miłosierdzia i w budowanie społeczeństwa obywatelskiego (KDK 88) $)^{55}$. Jednym z uczestników Soboru był kardynał Karol Wojtyła, który po powrocie z Rzymu zamierzał jak najszybciej wprowadzić postanowienia soborowe w Archidiecezji Krakowskiej i w tym celu zwołał specjalny synod ${ }^{56}$. Od początku pontyfikatu Jana Pawła II w jego nauczaniu znajduje się wiele odniesień do problematyki wolontariatu, a w latach 1979 -2001 odniósł się do niej aż 170 razy. W centrum Jego uwagi był wolontariat inspirowany wartościami chrześcijańskimi i jednocześnie nacechowany

${ }^{53}$ Por. M. Wyszyńska, Źródła i motywy zachowań prospołecznych, w: P. Bury, D. Czajkowska-Ziobrowska (red.), Edukacja bez granic - mimo barier, Poznań 2008, s. 206-207.

${ }^{54}$ D. Giers, P. Krakowiak, dz. cyt., s. 270-272.

${ }_{55}$ Por. Konstytucja duszpasterska o Kościele w świecie współczesnym Gaudium et spes, w: Dokumenty Soboru Watykańskiego II, Poznań 2002 - w tekście KDK z odnośnym numerem.

56 Prace synodu trwały od roku 1972. Jego założenia są opisane w: K. Wojtyła, U podstaw odnowy. Studium wprowadzania w życie Soboru Watykańskiego II, Kraków 1972. 
humanistyczną wrażliwością. Według Ojca Świętego najgłębszą motywacją do wolontaryjnej służby jest miłość do człowieka, która znajduje swe źródło w miłości Chrystusa do wszystkich, a szczególnie do słabych i pokrzywdzonych przez $\operatorname{los}^{57}$.

Praca wolontariusza jest znakiem miłości dla świata i drugiego człowieka poprzez „bezinteresowny dar z siebie" ${ }^{98}$. Najwyższym ideałem chrześcijańskiego wolontariatu jest Chrystus, który „nie przyszedł, aby Mu służono, lecz aby służyć i dać swoje życie na okup za wielu" (Mk 10, 45) ${ }^{59}$. Papież nie waha się stwierdzić, iż chrześcijański wolontariat jest jakby żywym i ciagłym zwiastowaniem obecności Chrystusa, który zawsze towarzyszy ludzkości w drodze. Objawia się w nim miłosierdzie Chrystusa wobec biednych, cierpiących, zapomnianych, zepchniętych na margines społeczeństwa i odrzuconych ${ }^{60}$. Jednocześnie Ojciec Święty przypomina, iż chrześcijanin zaangażowany w wolontariat uczestniczy w misji Kościoła i poprzez swoje «tak» otwarte na służbę choremu i biednemu bierze udział w misji zbawczej Chrystusa. Razem z Nim buduje królestwo Boże i wypełnia jakby posłannictwo apostolskie ${ }^{61}$.

Jan Paweł II traktuje wolontariat jako swoisty fenomen naszych czasów. Dostrzega w nim niewyczerpalne bogactwo, będące siłą napędową odnowy społeczno-politycznej i cywilizacyjnej ${ }^{62}$. W wolontariacie wyraża się odpowiedzialność całej społeczności, czerpiącej inspiracje z odwiecznych i niezmienne istotnych wartości ludzkich i chrześcijańskiej tradycji. Przeciwstawiając się egoizmowi i przemocy obecnym w świecie, staje się on antidotum na kryzys znaczenia wartości. Chrześcijański wolontariat jest świadectwem miłości braterskiej i wierności Ewangelii i jako taki ma wpływ na przyszłość ludzkości ${ }^{63}$. Do pełnienia zaszczytnej i wzniosłej misji wolontariatu nie mogą wystarczyć jedynie spontaniczność i ofiarność, potrzeba również odpowiedniego przygotowania ${ }^{64}$. Początkowy entuzjazm musi być wsparty cierpliwym pogłębianiem wiedzy oraz nauką wytrwałości. Stale odnawiana i pogłębiana motywacja działania, determinacja do pokonywania trudności,

57 Ten i kolejne cytaty z: Insegnamenti di Giovanni Paolo II [Nauczanie Jana Pawta II], Librreria Editrice Vaticana, 1978-2005, CD-ROM. Jan Paweł II, Przemówienie do Biskupów Pulii, 20.12.1986.

${ }_{58}$ Tenże, Przemówienie w nowootwartym centrum Caritasu, 25.11.1989.

59 Tenże, Przemówienie do Prezydenta Republiki Włoskiej, 10.04.1985.

${ }^{60}$ Tenże, Przemówienie podczas modlitwy Anioł Pański, 19.11.1986.

${ }^{61}$ Tenże, Przemówienie do uczestników Zgromadzenia plenarnego Papieskiej Rady ds. Duszpasterstwa Stuzby Zdrowia, 1.03.1994.

${ }_{62}$ Tenże, Orędzie na Światowy Dzień Misyjny, 30.05.1982.

${ }_{63}$ Tenże, Przemówienie do młodych, 26.09.1993.

${ }^{64}$ Tenże, Przemówienie do stowarzyszeń Caritas Italia, 20.09.1979. 
formacja ludzka i chrześcijańska powinny charakteryzować postawę wolontariusza. Ochotnicy powinni być wspierani przez wychowawców i koordynatorów wolontariatu, a jednym $\mathrm{z}$ ważnych zadań duszpasterzy i świeckich jest towarzyszenie tym, którzy przychodzą, by z zaangażowaniem służyć innym $^{65}$.

Wolontariat katolicki, zdaniem Jana Pawła II, posiada szczególny, ponadnaturalny charakter, poprzez ewangeliczne zakorzenienie $\mathrm{w}$ osobie Jezusa i w tradycji służby Kościoła wobec potrzebujących ${ }^{66}$. Nie realizuje się jednie na płaszczyźnie naturalnej pomagania w potrzebie, ale stara się podnieść miłość do człowieka na wysokość miłości Chrystusa. Jego celem jest przywracanie świadomości, że w oczach Bożych każdy człowiek, a szczególnie osoba cierpiąca, ma nieoszacowaną wartość i godnośćc7. Do opisania postawy chrześcijańskiego wolontariatu Jan Paweł II najczęściej używa następujących terminów: otwartość, dojrzałość, dyskrecja, hojność, szacunek, nadzieja, inicjatywa, ubóstwo, miłość, czystość, umiarkowanie, łagodność, poświęcenie, przejrzystość, stałość, wiarygodność, cierpliwość, chęć dawania, poszanowanie osoby, duchowość i optymizm ${ }^{68}$. Wymieniając wzory postaw służebnych, nie można pominąc akcentów maryjnych, tak bardzo obecnych w nauczaniu Papieża Polaka. Maryja wypowiadająca słowa: „Oto ja, niech mi się stanie według Twego słowa”, podążająca „z pośpiechem w góry" w służebnej misji wobec krewnej Elżbiety, jest pierwszą ikoną chrześcijańskiego wolontariatu. Odbija się w Niej echo zasadniczego fiat, które wypowiada Syn wobec Ojca: „Oto przychodzę, bo jest o mnie napisane, abym czynił Twoją wolę" (Hbr 10,7).

Szczególną rolę wolontariat odgrywa w świecie służby zdrowia i pomocy społecznej - w szpitalach, hospicjach, domach pomocy, a także w innych centrach pomocy ludziom w kryzysie. W przemówieniu do przedstawicieli zakonów szpitalniczych Papież podkreślił, że w służbie chorym i cierpiącym konieczne są takie wartości, jak: prostota, skromność, umiarkowanie, duch poświęcenia i zdolności dawania ${ }^{69}$. Wolontariusz, który pełni swoją posługę w placówkach służby zdrowia, tworzy razem z ich pracownikami jedną wspólnotę - rodzinę zatroskaną o dobro chorego, któremu służy ${ }^{70}$. Każdy we właściwym sobie zakresie powinien współpracować w zespole na rzecz

${ }^{65}$ Tenże, Przemówienie do uczestników zgromadzenia FOCSIV, 25.02.1984.

${ }^{66}$ Por. Papieska Rada ds. Służby Zdrowia, Zakonnicy w świecie cierpienia i zdrowia, Watykan 1987.

${ }^{67}$ F. Osella, La parola del papa ai sofferenti [Stowo Papieża do cierpiacych], Roma 1994, s. 178.

${ }_{68}$ Jan Paweł II, Przemówienie na zakończenie roku, 31.12.1990.

69 Tenże, Przemówienie podczas pielgrzymki do Lucca, 23.09.1989.

70 Tenże, Przemówienie w Szpitalu S. Camillo, 3.07.1983. 
chorego i dla jego dobra. W nauczaniu papieskim znalazły się także słowa uznania dla wolontariatu hospicyjnego, docenionego zarówno podczas pielgrzymki Ojca Świętego do Polski w 1987 roku $^{71}$, jak również w czasie spotkań z przedstawicielami opieki paliatywno-hospicyjnej i wolontariuszami hospicyjnymi ${ }^{72}$. Szczególną bliskość wobec wszystkich pracowników i wolontariuszy ośrodków paliatywno-hospicyjnych w kraju Jan Paweł II okazał w niedzielę 7 listopada 2004 roku, podczas ogólnopolskiej kampanii edukacyjnej „Hospicjum to też Życie”. W czasie modlitwy Anioł Pański z watykańskiego wzgórza skierował do nich słowa pełne otuchy i nadziei, które za pośrednictwem radia i telewizji usłyszał cały świat: „Troska, jaką pracownicy i wolontariusze otaczają osoby nieuleczalnie chore i umierające, jest wielkim dziełem miłosierdzia. Proszę Boga, aby wynagradzał ich miłość i oddanie swoimi łaskami. Polecam opiece Matki Najświętszej również tych, którzy towarzyszą cierpiącym we własnych rodzinach. Niech Bóg wszystkim błogosławi" 73 .

Swoistą syntezę nauczania Jana Pawła II o wolontariacie chrześcijańskim stanowi orędzie wygłoszone na zakończenie Międzynarodowego Roku Wolontariatu, ustanowionego przez Organizację Narodów Zjednoczonych. Tytuł tego przemówienia Miłość najwspanialsza forma ewangelizacji ukazuje najgłębszy sens chrześcijańskiej służby, w tym również wolontariatu hospicyjnego. Ojciec Święty wyraża w nim osobiste podziękowania dla ochotników, które można uznać za podsumowanie Jego nauczania o wolontariacie:

Drodzy bracia i siostry, którzy współtworzycie tę armię pokoju obecną w każdym zakątku ziemi, jesteście znakiem nadziei w naszych czasach. Wszędzie tam, gdzie mamy do czynienia z brakiem nadziei i cierpieniem, otwieracie niewyczerpane źródła poświęcenia, dobroci posuniętej aż do heroizmu, które wypływają z ludzkiego serca. Jako rzecznik ubogich całego świata pragnę podziękować wam za nieustanne poświęcenie ${ }^{74}$.

\section{Wolontariat w nauczaniu Benedykta XVI}

Ojciec Święty Benedykt XVI ukazywał najgłębszą motywację chrześcijańskiego wolontariatu podkreślając, że służba wolontariacka jest naj-

${ }^{71}$ Tenże, Przemówienie do chorych i stużby zdrowia, Gdańsk 12.06.1987.

72 Tenże, Przemówienie do uczestników 19 Konferencji Papieskiej Rady ds. Duszpasterstwa Stużby Zdrowia, poświęconej Opiece Paliatywnej, 12.11.2004.

${ }_{73}$ Por. Serwis Radia Watykańskiego, 7.11.2004.

${ }^{74}$ Jan Paweł II, Orędzie na zakończenie Międzynarodowego Roku Wolontariatu, 5.12.2001. 
wyższym wyrazem chrześcijańskiej miłości i kontynuacją dzieła dobrego Samarytanina. W pierwszej encyklice Deus Caritas Est pisze o ogromnym znaczeniu wolontariatu w Kościele i społeczeństwie. Warto przytoczyć tutaj cały rozdział tego papieskiego dokumentu:

Jak pokazuje przykład dobrego Samarytanina, caritas chrześcijańska jest przede wszystkim odpowiedzią na to, co w konkretnej sytuacji stanowi bezpośrednią konieczność: głodni muszą być nasyceni, nadzy odziani, chorzy leczeni z nadzieją na uzdrowienie, więźniowie odwiedzani itd. Organizacje charytatywne Kościoła, począwszy od Caritas (diecezjalnej, narodowej i międzynarodowej) muszą zrobić wszystko, co możliwe, aby były do dyspozycji odpowiednie środki i nade wszystko, by byli ludzie, którzy podejmą takie zadania. Gdy chodzi o posługę spełnianą wobec cierpiących, potrzeba przede wszystkim kompetencji profesjonalnych: niosący pomoc powinni być przygotowani w taki sposób, aby potrafili robić to, co właściwe we właściwy sposób, podejmując wysiłek dalszej troski. Kompetencja zawodowa jest tu pierwszym, podstawowym wymogiem, ale ona sama nie wystarczy. Chodzi bowiem o istoty ludzkie, a one zawsze potrzebują czegoś więcej niż technicznie poprawnej opieki. Potrzebują człowieczeństwa. Potrzebują serdecznej uwagi. Ci, którzy działają w instytucjach charytatywnych Kościoła, powinni odznaczać się tym, że nie ograniczają się do sprawnego wypełnienia, co stosowne w danej chwili, ale z sercem poświęcają się na rzecz drugiego, w taki sposób, aby doświadczył on bogactwa ich człowieczeństwa. Dlatego takim pracownikom, oprócz przygotowania profesjonalnego, potrzeba również i nade wszystko formacji serca: trzeba ich prowadzić ku takiemu spotkaniu z Bogiem w Chrystusie, które by budziło w nich miłość i otwierało ich serca na drugiego, tak aby miłość bliźniego nie była już dla nich przykazaniem nałożonym niejako z zewnątrz, ale konsekwencją wynikającą z ich wiary, która działa przez miłość (por. Ga 5, 6) (DCE 31) ${ }^{75}$.

Według Benedykta XVI, program chrześcijański to w dużej mierze program dobrego Samarytanina, który w najwyższym stopniu zrealizował sam Jezus Chrystus. Ten program to „serce, które widzi”, gdzie potrzeba miłości i działa konsekwentnie. Wolontariusze wierzący w Jezusa Chrystusa to serca i oczy, które dostrzegają potrzeby i cierpienia braci. Podczas pielgrzymki do Austrii 10 września 2007 roku w Wiedniu Benedykt XVI specjalnie zarezerwował czas na spotkanie się z nimi i skierował do nich słowa pełne entuzjazmu i wdzięczności ${ }^{76}$ :

${ }^{75}$ Benedykt XVI, Encyklika Deus Caritas Est, Watykan 2007 - w tekście DCE z odnośnym numerem.

${ }^{76}$ Tenże, Przemówienie podczas spotkania ze światem wolontariatu, Wiedeń 9.09.2007. 
Pięknie jest spotkać osoby, które w naszej społeczności starają się nadać Ewangelii oblicze; zobaczyć starszych i młodych, którzy konkretnie czynią doświadczalną w Kościele i społeczności tę miłość, poprzez którą my jako chrześcijanie mamy być zdobyci: to miłość Boga, który pozwala nam rozpoznać w drugim bliźniego, brata lub siostrę! Jestem pełen wdzięczności i uznania za wielkie zaangażowanie na rzecz wolontariatu tylu osób. Takie zaangażowanie daje przede wszystkim okazję, aby kształtować własną osobowość i włączyć się aktywnie i odpowiedzialnie w życie społeczne.

Podstawą tego zaangażowania - kontynuował papież - jest miłość.

Nie można jej delegować. Nie mogą jej zastąpić struktury państwowe czy polityka: Miłość bliźniego wymaga zawsze zaangażowania osobistego, dla którego państwo z pewnością powinno tworzyć sprzyjające warunki. Dzięki temu zaangażowaniu pomoc zachowuje swój ludzki wymiar, dlatego wy, wolontariusze jesteście osobami, które wnoszą rzeczywisty wkład w kształtowanie społeczeństwa o ludzkim obliczu.

Na uwage zasługuje też apel, jaki Benedykt XVI skierował podczas tego spotkania do młodzieży. Podkreślił, iż młodzi pragną, aby zostały w nich wzbudzone i odkryte talenty. Wolontariusze pragną być wezwani do działania osobiście: „Potrzebuję cię!”, „Poradzisz sobie!”. Ich działanie przeciwstawia się kulturze, w której wszystko ma swoją cenę i domaga się zapłaty. Podstawą jest darmowość. ,Zaangażowanie w wolontariat stanowi echo wdzięczności i jest przekazaniem miłości, jaką otrzymaliśmy"77.

O priorytetowym traktowaniu wolontariatu przez Benedykta XVI świadczą również słowa skierowane do polskich biskupów podczas ich wizyty ad limina Apolstolorum, która miała miejsce w 2005 roku. Wskazując na ważne pola duszpasterskiej aktywności, Ojciec Święty wymienił dzieła wolontariatu.

Chciałbym zwrócić uwagę na jeszcze jeden wymiar zaangażowania świeckich w Kościele. W dzisiejszym świecie, wraz z globalizacją i szybkim przepływem informacji, dostrzegamy w wielu środowiskach wzrost wrażliwości na potrzeby innych i gotowość przychodzenia z pomocą wszędzie tam, gdzie kogoś spotyka nieszczęście. Napawają nadzieją akcje humanitarne prowadzone przez organizacje kościelne i świeckie na rzecz ofiar klęsk żywiołowych i innych katastrof. Obok międzynarodowych i krajowych inicjatyw rozwijają się różne formy wolontariatu, które stawiają sobie za cel pomoc ludziom potrzebującym

77 Tamże. 
w najbliższym środowisku. W hospicjach, schroniskach dla bezdomnych, dla uzależnionych, dla samotnych matek i ofiar przemocy działają ludzie gotowi poświęcić swój czas dla służby innym. Niosą też pomoc chorym, samotnym, rodzinom wielodzietnym i cierpiącym biedę, osobom upośledzonym fizycznie lub umysłowo. Organizowane są ośrodki interwencji kryzysowej i instytucje służące pomocą osobom przeżywającym różnorakie trudności życiowe. Nie można nie doceniać dzieła tych, którzy wzorują się na przykładzie ewangelicznego Samarytanina. Trzeba to dzieło wspierać i animować. Wiem, że w Polsce wciąż rozwija się też wolontariat, który stawia sobie za cel obronę ludzkiego życia. Należy się wdzięczność wszystkim, którzy podejmują dzieło edukacji, przygotowania do życia w małżeństwie i rodzinie i stają w obronie prawa każdej istoty ludzkiej do życia od poczęcia do naturalnej śmierci. Wielu angażuje w tę działalność swoje własne środki materialne i swój czas, inni zaś składaja dar modlitwy. Wszyscy oni oczekują zachęty i moralnego wsparcia ze strony biskupów, kapłanów i całej wspólnoty wierzących. Niech tej pomocy im nie braknie! ${ }^{78}$

Najpełniej o roli wolontariatu chrześcijańskiego mówią słowa Ojca Świętego Benedykta XVI, dotyczące dobroczynności i wolontariatu w jego Encyklice Deus Caritas Est:

Ważnym zjawiskiem w naszych czasach jest powstanie i rozszerzanie się różnych form wolontariatu, które wyrażają się w wielorakich posługach. Pragnę wyrazić moje uznanie i wdzięczność wszystkim, którzy w jakikolwiek sposób uczestniczą w tej działalności. To szerokie zaangażowanie stanowi dla młodych szkołę życia i uczy solidarności, gotowości do dawania nie tylko czegoś, ale siebie samych. Anty-kulturze śmierci, która wyraża się na przykład w narkotykach, przeciwstawia w ten sposób miłość, która nie szuka siebie samej, ale która właśnie w gotowości «utracenia siebie» (por. Łk 17, 33 i nn.) dla drugiego jawi się jako kultura życia (DCE 30).

\section{Papież Franciszek i adhortacja Evangelii Gaudium (Radość Ewangelii)}

Papież Franciszek od pierwszych dni swojego pontyfikatu jasno wskazał, że centralne w Jego nauczaniu i życiu Kościoła jest posługiwanie potrzebującym, które we współczesnym świecie jest realizowane przy zaan-

${ }^{78}$ Tenże, Przemówienie do III grupy Biskupów polskich podczas wizyty ad limina Apostolorum, „L'Osservatore Romano”, 17 grudnia 2005. 
gażowaniu wolontariuszy. On sam w Wielki Czwartek 2013 roku stał się w pewnym sensie jednym $z$ wolontariuszy, odwiedzając i myjąc nogi młodym ludziom w więzieniu dla nieletnich w Rzymie. Doceniając pomoc wielu młodych ludzi w Brazylii, papież Franciszek znalazł czas, aby spotkać się z wolontariuszami pracującymi nad przygotowaniem i przeprowadzeniem Światowych Dni Młodzieży w Rio de Janeiro w 2013 roku. Przed wyjazdem z Brazylii papież Franciszek spotkał się z około 15000 wolontariuszami w Centrum Kongresowym w Rio de Janeiro. Była to część z ponad 60000 ochotników, którzy pracowali w ciagu ostatnich dwóch lat, przygotowując się do Światowego Dnia Młodzieży w Brazylii. Ojciec Święty wyraził wdzięczność za pracę wolontariuszy w słowach:

Drodzy Wolontariusze i Wolontariuszki, dobry wieczór! Nie mogłem powrócić do Rzymu bez podziękowania najpierw w sposób osobisty i serdeczny każdemu z was za waszą pracę i za poświęcenie, z jakim towarzyszyliście, pomagaliście, posługiwaliście tysiącom młodych pielgrzymów. Za tak liczne małe gesty, które sprawiły, że ten Światowy Dzień Młodzieży był niezapomnianym doświadczeniem wiary. Uśmiechami każdego z was, uprzejmością, gotowością posługi dowiedliście, że „więcej szczęścia jest w dawaniu aniżeli w braniu” (Dz 20, 35). (...) Wam, którzy w tym okresie tak szybko i wielkodusznie odpowiedzieliście na wezwanie, by zostać wolontariuszami na Światowym Dniu Młodzieży, chciałbym powiedzieć: bądźcie zawsze wielkoduszni wobec Boga oraz innych ludzi: niczego się nie traci, przeciwnie, tym, co się otrzymuje, jest wielkie bogactwo życia! ${ }^{79}$

Papież Franciszek spotkał się z wolontariuszami także w Watykanie na zakończenie Roku Wiary i podziękował im za ich pracę. Powiedział, iż potrzeba świadków, którzy gestem miłości i delikatności pomogą wierze się narodzić. Ojciec Święty przypomniał, że ten czas łaski pomógł wielu ludziom odnaleźć to, co istotne dla życia chrześcijańskiego, w którym wiara razem $\mathrm{z}$ miłosierdziem zajmuje pierwsze miejsce.

Wiara jest fundamentem życia chrześcijańskiego, ponieważ motywuje nasze wybory i codzienne decyzje - powiedział Papież. - Jest niewyczerpanym źródłem całego naszego działania: w rodzinie, pracy, parafii, wśród przyjaciół i w różnych wymiarach życia społecznego. Tę wytrwałą, szczerą wiarę szczególnie widać $\mathrm{w}$ chwilach trudności i próby. Wtedy właśnie chrześcijanin po-

${ }^{79}$ Franciszek, Spotkanie z Wolontariuszami, Przemówienie Ojca Świętego, Pawilon 5 w Rio Centro, Rio de Janeiro, 28 lipca 2013, za: http://www.vatican.va/holy_father/francesco/ speeches/2013/ (styczeń 2014). 
zwala się wziąć Bogu na ręce, wtula się w Niego, mając pewność, że powierza siebie miłości mocnej jak niezniszczalna skała. Właśnie w sytuacjach cierpienia, jeśli pokornie zdamy się na Boga, możemy dać wspaniałe świadectwo.

Papież zauważył, że dzięki swej posłudze w ciagu Roku Wiary wolontariusze wielokrotnie byli świadkami tego, jak wiara staje się siłą napędową nowej ewangelizacji. Przypomniał, że świat wciąż potrzebuje, by orędzie Chrystusa zanieść wszędzie tam gdzie jest człowiek, szczególnie w środowiska najbardziej trudne ${ }^{80}$.

W Encyklice papieża Franciszka Evangelii Gaudium natrafimy na słowa zachęty do zaangażowania świeckich wolontariuszy w dziele Kościoła i działalności charytatywnej:

Świeccy stanowią olbrzymią większość Ludu Bożego. W ich służbie pozostaje mniejszość: wyświęceni szafarze. [...] Nawet jeśli zauważa się większe uczestnictwo wielu w posługach świeckich, zaangażowanie to nie znajduje odzwierciedlenia w przenikaniu wartości chrześcijańskich do życia społecznego, politycznego i ekonomicznego. Często ogranicza się do zadań wewnątrzkościelnych bez rzeczywistego zaangażowania w zastosowanie Ewangelii w dzieło przekształcenia społeczeństwa. Formacja świeckich oraz ewangelizacja różnych środowisk zawodowych i intelektualnych stanowią ważne wyzwanie duszpasterskie (EG 102) ${ }^{81}$.

W tym dokumencie Ojca Świętego Franciszka możemy przeczytać istotne słowa dotyczące wolontariatu w odniesieniu do szukania Boga we współczesnym świecie i odkrycia właściwego powołania w życiu, co jest również jednym z celów edukacyjnych.

Nawet jeśli nie zawsze łatwo jest podejść do młodych, dokonany został postęp w dwóch sferach: w świadomości, że cała wspólnota ich ewangelizuje i wychowuje oraz że pilna jest potrzeba, aby mieli oni większy wpływ. Trzeba przyznać, że w aktualnym kontekście kryzysu zaangażowania i więzi wspólnotowych, wielu młodych ludzi ofiaruje swą solidarną pomoc wobec chorób świata i podejmuje różne formy walki i wolontariatu. Niektórzy uczestniczą w życiu Kościoła, angażują się w grupach pełniących służbę lub w różne inicjatywy misyjne w swoich diecezjach albo w innych miejscach. Jakie to piękne, że młodzi

${ }^{80}$ Por. Radio Watykańskie, 25.11. 2013,w: www.radiovaticana.va/pol_RG/2013/Novembre/13_11_25.html

${ }^{81}$ Franciszek, Adhortancja apostolska Evangelii Gaudium, Watykan 2013 - w tekście EG z odnośnym numerem. 
są «pielgrzymami wiary», szczęśliwi, że mogą nieść Jezusa na każdej ulicy, na każdym placu, w każdym zakątku ziemi! (EG 106).

\section{Zakończenie: Przyszlość wolontariatu w Polsce}

Przedstawione powyżej analizy rozwoju pojęcia wolontariatu, przykłady badań i tekstów z zakresu nauk o wychowaniu i teologicznych rozważań zaczerpniętych z nauczania papieży XXI wieku pozwalają zrozumieć wartość i znaczenie wolontariatu w działalności pedagogicznej, a także pastoralnej i charytatywnej Kościoła i współczesnego społeczeństwa. W 2011 roku z inicjatywy Unii Europejskiej odbył się Rok Wolontariatu. Odbyło się wiele wydarzeń międzynarodowych, krajowych i regionalnych, w których aktywnie uczestniczyli także wolontariusze z Polski. Ważnym dla wizji rozwoju wolontariatu w Polsce stał się dokument Dlugofalowa polityka rozwoju wolontariatu $w$ Polsce. Rekomendacje ukazują potrzeby dotyczące aktywizacji społecznej i wsparcia legislacyjnego oraz promocji wolontariatu w społeczeństwie ${ }^{82}$. Zarówno wnioski z badań dotyczących wolontariatu w opiece paliatywno-hospicyjnej ${ }^{83}$, jak i wieloletnia praktyka organizowania i kierowania ochotniczymi działaniami w strukturach Kościoła katolickiego i społeczności lokalnych w Polsce potwierdzaja, iż rozwój działań wolontariatu jest możliwy. Potrzeba, by zaproszeniu do ochotniczej pomocy towarzyszyły przygotowanie merytoryczne organizatorów wolontariatu, a także życzliwość osób i instytucji, w których wolontariusze mają współpracować z profesjonalistami. Potrzebne są szkolenia dla koordynatorów wolontariatu, włączanie ochotników do zespołów opiekuńczych i parafialnych, czy należne miejsce dla nich w strukturach szkolnych ${ }^{84}$. Konieczne są właściwa komunikacja i wyjaśnienie ról dla wolontariuszy wewnątrz instytucji pomocowych, do czego niezbędne jest przygotowanie koordynatorów wolontariatu, odpowiedzialnych za rekrutację, szkolenia i organizację działań ochotników. Do dalszego rozwoju wolontariatu i włączania go do nauczania Kościoła katolickiego potrzebna jest edukacja społeczności lokalnych i zachęta do włączenia się w wolontariat. Może się to dokonywać poprzez nauczanie we wspólnotach parafialnych, ale także przez prelekcje w szkołach, parafiach,

${ }^{82}$ Dlugofalowa polityka rozwoju wolontariatu w Polsce, Warszawa 2011, za: http:// erw2011.gov.pl/static/upload/dugofalowa-polityka_300811_fin.pdf (styczeń 2014).

${ }^{83}$ P. Krakowiak, Społeczne i edukacyjne funkcje opieki paliatywno-hospicyjnej. Badania $w$ działaniu, Gdańsk 2012.

${ }^{84}$ Por. J. Binnebesel, A. Janowicz, P. Krakowiak (red.), Jak rozmawiać z uczniami o końcu życia i wolontariacie hospicyjnym, Gdańsk 2009. 
w klubach seniora ${ }^{85}$. Wolontariat może się rozwijać, jeśli poważnie zostaną potraktowane czas i energia, ofiarowane osobom i instytucjom. Wypowiedzi Pasterzy Kościoła Powszechnego, zaprezentowane w tej publikacji niech będą zachętą do dalszego badania zjawiska wolontariatu, a także do praktycznego wspierania ochotników, pragnących nieść pomoc innym i ofiarować swój czas i energię odpowiadając na powołanie do wolontariatu.

\section{Educational Functions of Volunteering and their Perception in the Teaching of the Catholic Church in the XXI century (Summary)}

Mutual assistance between people is a part of every civilization and society and therefore the history of volunteering is as ancient as the existence of mankind. Analysis of the history of volunteering helps in understanding today's meaning of voluntary sector and the development of this activity in the world, Europe and Poland. Educational sciences emphasize the educational functions of volunteering. Its particular value in the modern world is appreciated by the Catholic Church, demonstrated by statements of 21st century pontiffs: John Paul II, Benedict XVI and Francis. This analysis enables for an insight into roles which can by played by volunteer involvement in helping our neighbor in human and Christian formation. Reading of the texts referring to volunteering can serve as inspiration for both clergy and laity, to use volunteering to help those in need, but also for instruction through service to others and learning in practice, what is the interpersonal solidarity and Christian charity. This analysis is designed to help both theoreticians of pedagogy and Christian education, as well as practitioners who - in schools, parishes, or in the structures of Caritas and other charitable organizations - are involved in volunteering or coordinate it. The development of a voluntary commitment to the needy is a pressing social need in Poland and an opportunity to discover the vocation to Christian and humanistic activities which is both educational tool, possible to use in educational institutions and communities of faith.

Keywords: volunteering; education; vocation; motivation.

${ }^{85}$ Por. P. Krakowiak, Społeczne, s. 140-153. 


\section{Edukacyjne funkcje wolontariatu i ich percepcja w nauczaniu Kościoła w XXI wieku (Streszczenie)}

Wzajemna pomoc międzyludzka jest elementem każdej cywilizacji i społeczeństwa, dlatego historia wolontariatu jest równie antyczna, jak istnienie rodzaju ludzkiego. Analizując historię podejmowania działań ochotniczych, można lepiej zrozumieć dzisiejsze znaczenie terminu wolontariat i rozwój tej formy aktywności na świecie, w Europie i w Polsce. Nauki o wychowaniu podkreślają funkcje edukacyjne i wychowawcze wolontariatu. Jego szczególną wartość we współczesnym świecie docenia Kościół katolicki, co pokazują wypowiedzi papieży XXI wieku: Jana Pawła II, Benedykta XVI oraz Franciszka. Niniejsza analiza pozwala przyjrzeć się rolom, jakie ochotnicze zaangażowanie w pomoc bliźniemu odgrywać może w formacji ludzkiej i chrześcijańskiej. Lektura tekstów odnoszących się do wolontariatu może być inspiracją zarówno dla duchownych jak i świeckich, do wykorzystania wolontariatu do pomocy ludziom w potrzebie, ale także do wychowywania poprzez służbę innym i uczenia w praktyce, czym jest solidarność międzyludzka i chrześcijańskie miłosierdzie. Niniejsza analiza ma służyć pomocą zarówno teoretykom pedagogiki i wychowania chrześcijańskiego, jak również praktykom, którzy w szkołach, w parafiach czy w strukturach Caritas i innych organizacji charytatywnych są zaangażowani w wolontariat lub nim koordynują. Rozwój ochotniczego zaangażowania na rzecz potrzebujących jest pilną potrzebą społeczną w Polsce i szansą na odkrycie powołania do chrześcijańskiej i humanistycznej działalności, która jest jednocześnie narzędziem wychowawczym, możliwym do wykorzystania w instytucjach edukacyjnych i wspólnotach wiary.

Słowa kluczowe: wolontariat; wychowanie; źródła motywacji; powołanie. 